\title{
Rewriting the Journey of the Mantua-Peschiera Railway: A Moving Experience
}

\author{
Federico Marcolini
}

\begin{abstract}
The research presented in this article is embedded in the context of the on-going doctoral thesis titled The Mantua-Peschiera Railway: A Case Study for the Historical Analysis and Design Methodology of a Regeneration Project. The research focuses on the decommissioned railway that once connected the city of Mantua to Peschiera del Garda in the north of Italy and questions its possible future. Nowadays, the railway is not perceived as it was, because, without any specific or recognizable appearence, its few remains, such as the passenger stations, are in ruins. The historical data helped to reshape the original project of the line and its deep interdependence with its environment showing peculiar and original characters as a branch line. The author's research aims to create a possible scenario in which the former railway guarantees a continuous connection between the object and its territory within its new function as a Cultural Route.
\end{abstract}

Keywords: Literature Journey; Railways; Landscape; Historical Data.

This article refers to the theoretical framework used to retrace the experience of the railway journey - approaching the complexity of its context and its history - and allows us to move through the heterogeneity of the landscape using a different point of view. Starting from the information contained in the historical documents of the railway and enriched by maps and photographs, the territory of the Mincio Valley is described in order to emphasize the technical description of the territory. Moreover, the importance of a subjective approach is explained here with reference to the possibility of the Valley as a space in between and connecting cities, and in reference to the Grand Tour experience and the idea of a journey. 


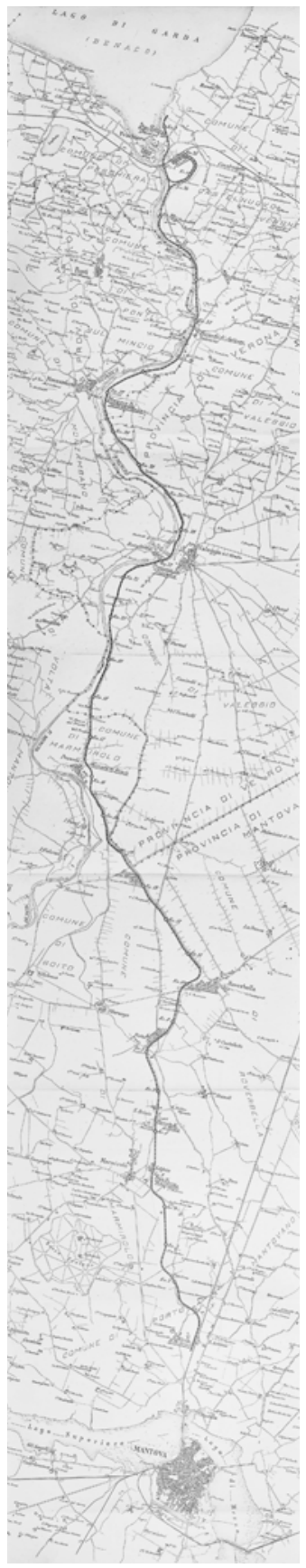

1.

Ferrovia Mantova-Peschiera, 1:25000 orig. Scale, General Plan, Ing. Arvedo Arvedi, 1905, Archivio di Stato di Mantova, Fondo Camera di Commercio, Parte Seconda, Busta 286,

Courtesy: Archivio di Stato di Mantova. 


\section{Introduction}

In 1905, the Italian Ministry of Transport required the submission of a preliminary draft of plans for the construction of a secondary railway line between the city of Mantua and Peschiera del Garda in the north of Italy. The preliminary draft was designed by the local engineer Arvedo Arvedi in the same year and it is the only document that has survived in which the railway is described. The folder contains several pamphlets including: a general plan (fig. 1.a-b), a technical report, a section on the various heights of the line and a financial report, proving its convenience and economic sustainability.

Retracing the route drawn in the plan, assisted by the description contained in the technical report, it is now possible to rewrite an immaginario $^{1}$ of the Mantua-Peschiera journey. A journey characterized not by the mere technical description of the railway, but in which the territory and its various landscapes are introduced: quoting ancient and partly forgotten toponyms and monumental features of the built environment (fig. 2) that have disappeared or transformed profoundly, and creating a hypothetical itinerary that, such as the immaginario of the railway itself with its layout and its artifacts, is made up of traces, whether they are still recognizable or have completely disappeared.

The journey offers a sequence of complex images which represent a contemporaneity, abstracted and suspended in an indeterminate space. The journey becomes the key to understanding the profound relationship between the railway infrastructure and its territory. A complex environment characterized by distinctive features, of which the Mincio river is the most dominant one. The particularity of this waterway, whose waters are never impetuous or violent, allowed the inhabitants of the valley to get closer to its banks, along which they have built mills, farms, noble residences, villages, and hamlets. Following the morphology of the Valley, it is possible to identify two different areas: The hills in the north part and the plain in the south. These peculiar characters defined different environments in which the anthropization process generated a heterogeneity of landscapes. Since ancient times, these places have been characterized by the strong presence

\footnotetext{
1 The Italian term immaginario (imaginarius in Latin) is considered here as a function and content of the imagination. A controlled imaginative, as suggested by Kant, in which limits upon the surreal are placed, a productive imagination is that which coincides with the functions of the pure intuition of space and time.
} 


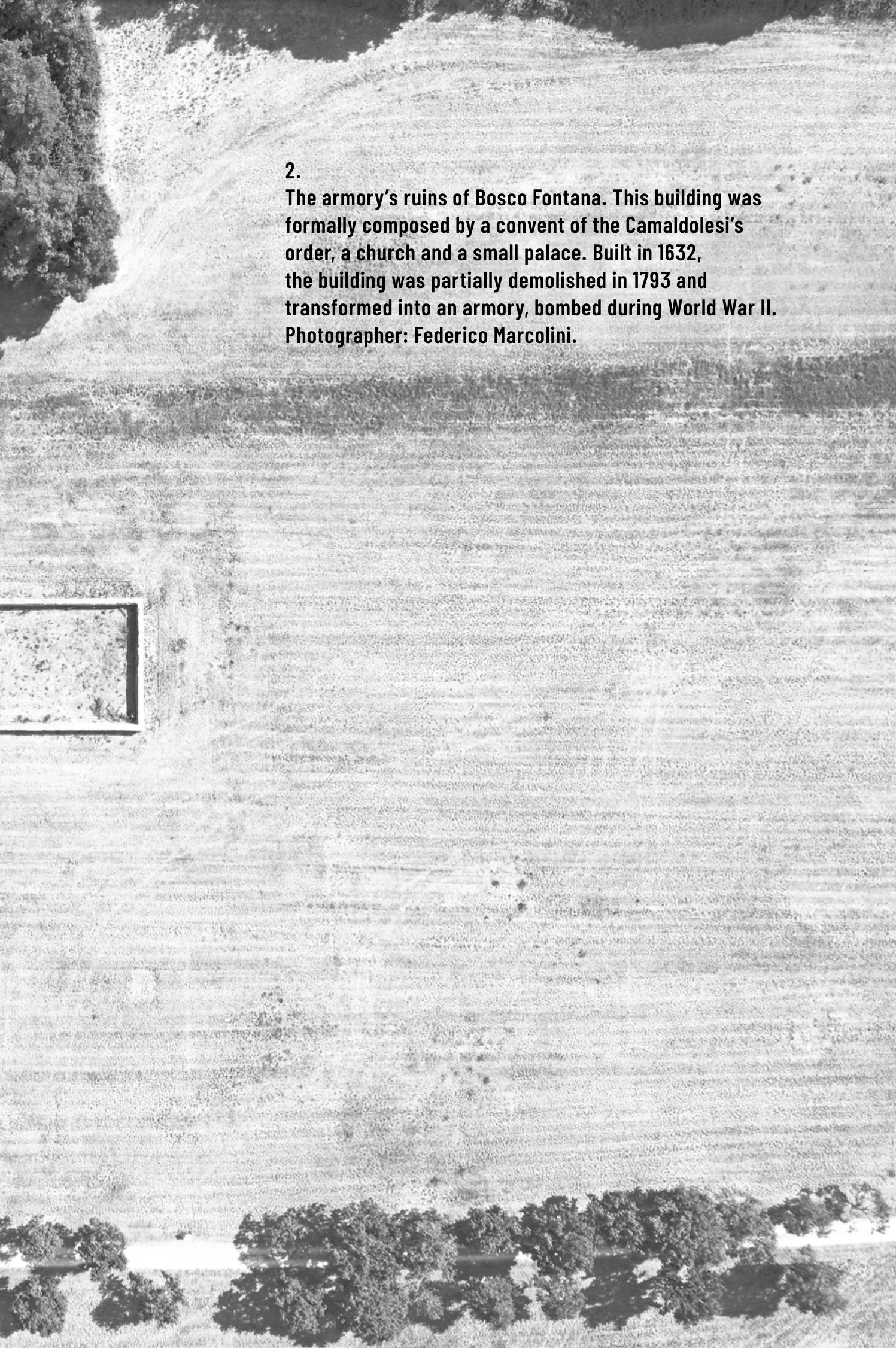


of mankind. During the Roman era, centuriation came to surround the limits of the Valley without ever getting to occupy it because of its soil characteristics. It is in fact its nature that imposed a continuous domestication of the land, with the construction of terraces on the slopes facing south and continuous tilling of the land from the stones brought to the valley when the primitive Benaco Glacier melted.

The imagined journey is considered as "a condition of a hermeneutic activity towards the built environment« (Lampugnani Savi 1987: 14), said Vittorio Magnago Lampugnani upon the occasion of the XVIIth edition of the Milan Triennale of 1987 entitled Un Viaggio in Italia, Nove Progetti per Nove Città. It is a subjective reading in which architectures, villages, and landscapes are in sequence, creating heterogeneity that, in the case of the Mantua-Peschiera experience, leads back to a contemporary unique layer of coexistence identified in the Mincio Valley and its river.

\section{The "Paese Reale" of the XVIIth Triennale}

The key contributions of this territorial's reading starts from the experiments conducted by Vittorio Magnago Lampugnani and Vittorio Savi for the construction of the above mentioned XVIIth Milan Triennale. At that time, the authors aimed to describe the Paese Reale (de Seta 2014), the real country, through an interpretation of the built environment, created by selective and arbitrary choices, and without claiming to be exhaustive. The co-curator, Pierluigi Nicolin, justifies this choice, saying that the city, like the anthropized territory, does not present itself as an organic unit and is exposed to different interpretations. The goal of Lampugnani's work was to look for models in the places he passed through and to "start to solve those environmental and redevelopment issues « (Nicolin 1987: 11, author's translation) and to be useful for the city, as Nicolin himself writes in the introduction to the exhibition catalog.

The reference materials attest to the journey of the imagined character Vittorio Valori Perduti and consist of paintings, drawings, models, and

2 The Paese Reale (the Real Country) to which Cesare De Seta refers, is the Italian Country »discovered «by the European consciousness in the modern age, thanks to the complex and tangled experience of the Grand Tour. A significant contribution to the culture of cosmopolitanism, in which the role assumed by Italy was fundamental as an aggregation center of civilization in modern Europe. 
publications "which guarantee the necessary arbitrariness of the point of view« (Nicolin 1987: 12, author's translation). The imagined traveler is at the same time a man of science who asks questions and looks for solutions, and a romantic one who leaves himself open to deeper and more emotional interpretations of the areas that lie between cities.

\section{„lo Osservo«, I Observe}

Looking at the Casabella editorials by Vittorio Gregotti, collected in "96 ragioni critiche del progetto « (Gregotti 2014), the architect talks about architecture's character as an artistic practice and its specialties with the empiric world of situations and conditions. He underlines the relevance of architecture's critical relationship with the real, and the context into which architecture fits as a fundamental reference: »I write about Homer telling that Ulysses heard the mermaids sing (Calvino 1980: 322, author's translation), wrote Italo Calvino in a famous essay on the ways and levels in which the notions of reality arrange themselves for the writer's sake, beginning with that "I write « and to what Gregotti says »is not an observation point but the ground for reality's transformation into literary substance« (Gregotti 2014: 2, author's translation).

Within the transcription and narration of reality some transformation and interpretation takes place. Like a poem, the observer clarifies the subjective point of view of the literary documentation in which architecture seeks to embody the depth of "its layers of implications and connections with the different levels of both the real and its disciplinary schematizations, by means of the project's "I write (ibid.). A subjective position, it is strenuously defended in order to guarantee the value of architectural projects and, therefore, of architecture itself.

A journey into culture, as Carlo Quintavalle reminds us in the introductory essay for the catalog of another exhibition: Viaggio in Italia. Curated by Luigi Ghirri and displayed in Bari in 1984, the exhibition "favors some objects over others in various eras« (Ghirri 1984: 8, author's translation). The imagined journey is a subjective experience that reconstructs the memories of places and through them reveals their original nature. An experience described by Gianni Celati in the contribution Verso la foce tells the story of traveling along the Po river in literary form as a reporter for his photographer friend (Ghirri 1984: 20-35). A trip similar to the one commissioned to Luigi Ghirri by Vittorio Savi for the paesaggio immagine e realtà 
exhibition, whose catalog was published by Electa in 1981 and in which the architect, Savi, leaves it to the photographer, »who had set a goal, free from aesthetic prejudices towards today's artificial environment« (Savi 1981: 275, author's translation); searching for a real country made up of things and in which people "have escaped from his frames, in which things and substitute goods have replaced them, in order to form an effective synecdoche: anthropological« (ibid.).

More recently, Marco Belpoliti, in his book Pianura, retraces the places he lived in the Po Valley and their memories, restoring a subjective reality formed by his culture and memory. An itinerary that recounts some peculiar features, such as the Roman centuriation or monumental buildings such as the Cathedral of Modena, helped by characters such as Christian Tuxen Falbe or friends of the past such as Luigi Ghirri and Gianni Celati (Belpoliti 2021). Here, architecture becomes an emblem of the history of a place, a transposition of a shared culture often cited in the works of those who describe it in literary form or through the poetics of photography.

It is an approach that shows visions of landscapes starting from the subjective mental disposition of those who place themselves on the observer's side:

»An unprecedented design dimension, where space and time enter, [...] in which the final image is the result of choices made more or less unconsciously by the subject: an experience that implies modes of representation coming from different cultural fields« (Spinelli 2019: 13, author's translation).

An internal point of view, an inscape, as the Irish Jesuit Gerard Manley Hopkins defined it, in which the natural landscape becomes the object of reflection upon his tormented vision of reality, like in his poems Binsey Poplars and Spring and Fall. 


\section{The Journey of "Vittorio Valori Perduti«}

In 1987, one year before the publication of Gregotti's original work in Casabella (Gregotti 1988), the Milan Triennale hosted the exhibitions »Viaggio in Italia« and »Nove progetti per Nove città « ${ }^{3}$, under the direction of Pierluigi Nicolin.

A journey that, through the gaze of a heteronomous character, like the ones described by Pessoa, crosses a sequence of places made by their architectures, cities, and landscapes, intended to declare their problems and to suggest new paths (Pessoa 2020). A visit to nine cities in which the protagonist collects the character for each one, "or rather the dominant flavor and behavior of it « (Lampugnani/Savi 1987: 14, author's translation). Through the heteronomy of the imagined protagonist and through the metaphor of travel, the places become the space of the project.

Along this journey, looking at the territories in between cities, the traveling experience is based on a narrative. The materials are chosen through the traveler's particular point of view and recall the different moments and situations related to the journey's experience. The different situations are: the start, the learning, the railway'quête, bewilderment, the stop, the endlessness, the death-city, the nostalgia, and the arrival. These are specific situations that define different sequences of architecture to be interpreted through the reading of an architect: Vittorio Valori Perduti (fig. 4) (Dal Lago 1987: 230).

The exhibition starts from history as a documentary basis for the definition of reference models for the construction of future cities and draws inspiration from identifying the environmental requalification themes necessary for the construction of new development scenarios for cities and territories.

Like the exhibition, the author's research also looks toward history for a model that can be used as a reference, a tool for the redevelopment of territories. An environmental redevelopment that takes issues related to the setting of architectural interventions on the remains of the former

3 The XVIIth Triennale di Milano with the exhibition »Le Città Immaginate: Un Viaggio in Italia. Nove progetti per nove città«, »ll progetto domestico« and »ll luogo del lavoro«, completed a series focused on Italian urban and architectural history. This was a trilogy related to the International Exhibition »Le città del mondo e il futuro delle metropoli« displayed at the Palazzo dell'Arte in Milan at the end of 1987. 


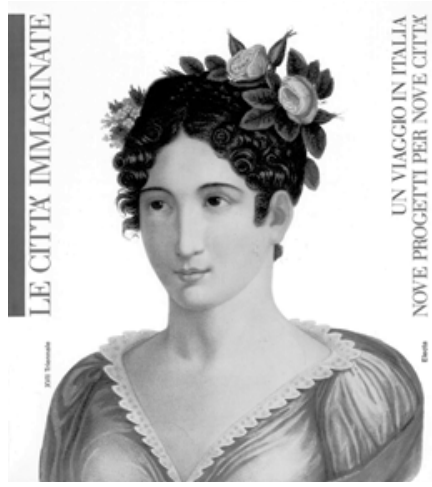

3. Catalog Cover of the XVIIth Milan Triennale, 1987. Courtesy: Triennale di Milano, Biblioteca e Archivi.

\section{CHIAMO}

Vittorio Valori Perduti. Quando prontenzio questo nome, mi credono di rado. Pensano sia un nome d'arte. Tuttavia conta poco che sia autentico; è rilevante che non esprima la contraddizione di cui sono preda. Per. ché da uen lato provo un'infinita nostalgia per ivalori dell' 'talia fisica e dell' Italia sociale che, assai prima della nascita di mio padre, cominciarono a franare; $e$ con la seconda rivoluzione industriale, notinarono; e, sot. to i miei occhi, per vari motivi da non rivangare qui, si dissolsero. Dall'altro il movimento della caltara architettonica, il movimento della ricerca professionale, il mio carattere, e tutto, tutto mi spinge a un lavoro positito, di ricomposizione, reintegrazione, insomma riavvalorizzazione. Cercherò di aturzare ten ecempio. Stamene sono passato dall'Eur. Eur: Esposizione unitersale di Roma... ho trascorso un'infanzia che mi ha dato pochi ricordi, come quando assisto alla proiezione di an film muto, o parlato in lingua straniera, senza sottotitoli in italiano. Fra i pochi c'e quello di tara imprevista breve visita alle costnezioni montementali del. [Esar, sospese nel 1941, non ancora terminate, già in rovina. Era apprento il primo dopoguecra. Gli zii mi ave. vano preletato a Termini e mi avevano portato a casa loro. A bitavano in un intensivo ficori Porta Metronia. Di li si faceva presto ad "andare al mare". E subito mi avevano ricaricato stlla 1100 per una gita. Lo zio era un piccolo imprenditore edile, che aveva costruito per ['ltalia fascista, e, prima di imboccare la strada, eoleva mostrami un quartiere mai teminato, mai entrato in funzione. Bastava un giro d'automobile: mi sarei meravigliato e avrei imparato qualche cosa. Sic transit... Una landa desolata. Al fondo di strade sterate songe vano tvaste architettere.-Si conserveranno pure delle stampe di foto scattate ai palazzi abbandonati sopra il logoro tappeto erboso: palazzi della Civiltà, dei Congressi, dell'Ina e dell'Inps.

Rimasi a bocca aperta; non so se fui ammaestrato.

Era bello, quel torso di cittc. E, quali che siano stati $i$ giadizi formalati in seguito, mi pare di poter sostener che non sarebbe stato mai più cosi attraente $e$ importante.

Doveva rimanere nello stato in cai lo rimirai allora. Al massimo, secondo che era stato programmato, bisognata completarlo con edifici residenziali, in stile 1942. Ma onmai..

Eppure. Vorrei mi affidassero l'incarico di provvedere al restanco dell'E42. Proverei a disegnare la forma di alcuni isolati che, innestati in posizioni opportane, farebbero balenare l'immagine di un' $\mathrm{E} 42$ integra 0 , se vo lete, propizierebbero an retto completamento mentale.

Fallissi io, forse non auxà fallito il coetaneo, lo stimato architetto F.P., che, a quanto mi consta, dell'Eur si c̀ occupato progettualmente. E se lui, come gli accade, avesse scambiato la necessitù di discgnare credi. bili anitả abitative con l'occasione per disegnare una scena a base di quinte, facciate dalle finestre tutte eguali e gran comicione, potrebbe tentare un terzo collega.

Guidando, fantasticato; mi sono persino scordato di guardare la Piramide di Caio Cestio e il palazzo posta. le di Libera, con ten colpo d'occhio che mi è caro.

La marea montante del traffico mi ha depositato nei pressi del Colosseo.

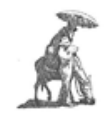

4.

The description of»Vittorio Valori Perduti« within the catalog of the XVIIth Triennale. 
Mantua-Peschiera railway and how they relate to their heritage and the landscapes it crosses.

Choosing the anthropized territory as our reference, we realize how the entire built environment cannot offer itself to our eye as an organic unit. The object of our interest is revealed as a text with multiple meanings, open to different readings. Looking for qualifying and functional interpretations, the metaphor for the journey became a means of accessing different interpretive materials from the territory once crossed by the railway. A look toward the horizon of those who, like Moby Dick's eager to travel boy, want to embark to see the world, and, approaching the old captain, was challenged to observe the infinity of the ocean. In the novel by Herman Melville, the old man posits the question: »Take a peep out that way and tell me what ye see there«, and the boy replies »not much stuff, nothing but water «, and the old man says: "Well, what dost thou think then of seeing the world? Do ye wish to go round Cape Horn to see any more of it, eh? Can't ye see the world where you stand? (Melville 1892: 78).

This is an episode in which sthere is no more radical and at the same time modest denial of the idea of travel as a physical fact « (Pontiggia 1987: 78 , author's translation), a provocation through which it is suggested we approach the world without leaving the door, a mental journey, just like the one imagined by the protagonist of Viaggio in Italia, curated by Vittorio Magnago Lampugnani and Vittorio Savi. A mental journey because, as Lao Tzu suggests, we should know the world without going out of the door (Pine 2009: 94).

Here, the journey is considered as a "condition of a hermeneutic activity towards [...] the built territory« (Nicolin 1987: 12, author's translation) which offers a sequence of complex images, which seem to represent an equally complex abstract and suspended contemporaneity within an indeterminate space (Camerlenghi 2003). It is an imagined journey that reshapes what anyone could have encountered crossing the Mincio Valley with its railway and beyond. It is a journey certified by materials such as the technical reports of the railway projects, images, and immaginari that, like the remains of the railway itself, have survived, even if only as signage in the landscape. 


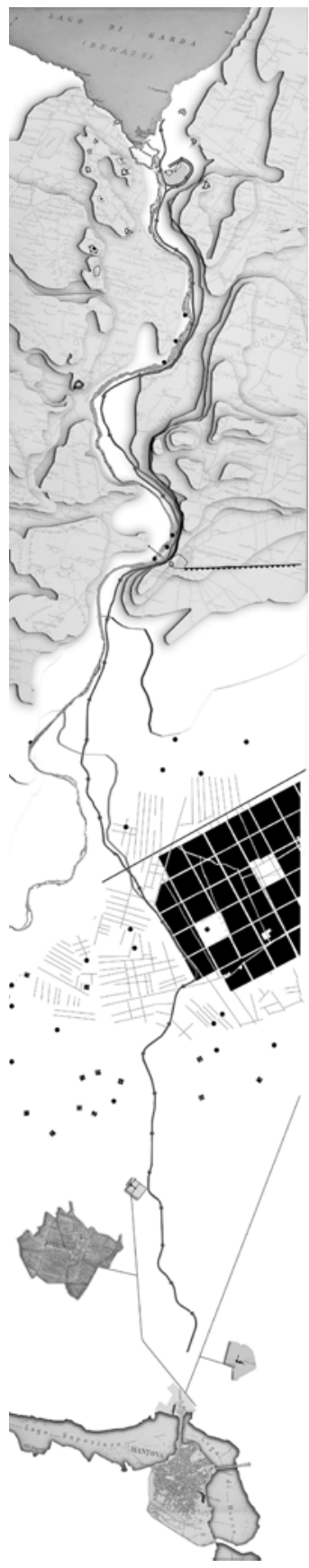

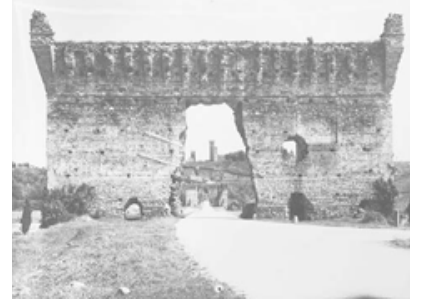

5.

The Ponte Visconteo in Valeggio sul Mincio, Calzolari, 1930(?), Archivio di Stato di Mantova Fondo Calzolari. Courtesy: Archivio di Stato di Mantova.
6.

The graphic representation of the MantovaPeschiera Journey, 2020.

Mapping: Federico Marcolini. 


\section{The Image of the Mincio Valley}

Like the imagined character of Vittorio Valori Perduti, who came out of Vittorio Lampugnani's mind, the traveler is, here too, a figure accompanied by different materials, able to guarantee the necessary arbitrariness of his point of view. The imagined journey is a subjective reading of a sequence of architectures, villages, and landscapes, a heterogeneity that leads back to a unique layer of coexistence and contemporaneity that could be identified in the Mincio Valley and its river.

Like Vittorio Valori Perduti, we can imagine his homonymous, a user of the short railway that connected the city of Mantua to the warm and welcoming shores of Lake Garda. This is a journey imagined and reconstructed through the railway projects, whose technical reports return short descriptions of the crossed landscapes, the photographs belonging to the Calzolari and Giovetti Fund of the Archivio di Stato di Mantua and the scientific publications relating to the Mincio and its territory (fig. 5).

It is therefore the interpretive dimension that characterizes the drafting of this imagined journey between Mantua and Peschiera. Within the author's research, the journey follows the description provided by the technical report of the general project carried out by the engineer Arvedo Arvedi in 1905 , assisted by extracts from the general plan of the same project. Thanks to that, some elements of the territory are highlighted and used to introduce an in-depth study useful to the definition of the immaginario linked to travel and places.

In turn, the insights are built on the basis of original documents such as descriptions, photographs, historical maps or drawings. Therefore, the journey is rewritten through a method which, having the railway as its incipit, opens up the territory without ever disconnecting from it. In addition the railway, being parallel to the course of the river, manages to become part of the landscape, thanks to the interaction among their elements.

\section{Conclusion}

From the different modes in which Vittorio Valori Perduti traveled, we refer here to the andare, "to go", in which the protagonist is accompanied in this vision by a connaisseur, a modern Virgilio, who is left with the burden of "providing the text, a story of experience, result of a protracted meditation and therefore a broad report, characterized by analytical thrusts« 
(Lampugnani/Savi 1987: 15, author's translation). At each crossing, a report is drawn up, a document that shows itself as a chronicle of the itinerary and which, instead of being a text, becomes its graphic representation in the form of a map (fig. 6), which, by its nature defined within a frame, focuses on the places imagined and lost in the memory of those who are accompanying us on this journey.

Another way of traveling is the stop. In the case of the Triennale, it refers to large cities in which the heteronomy of the protagonist allows for a new approach to the object, abandoning the connaisseur in favor of a scholar, a luminary capable of contributing to a critical and unique cut and reconstructing, through microstorie narrate, small stories, the tiles of a fundamental mosaic to "trace the authentic metonymic profile of the city « (Lampugnani/ Savi 1987: 16, author's translation). Yet, if the city is not the protagonist of this work, the stop is, in analogy with the railway and its main artifacts, such as the stations and stops that represent nothing but this. In these cases, the stop always takes place at an inhabited center, in an urbanized and highly man-made place, or a reference to a more or less large area, also man-made but characterized by a greater natural component.

As for the cities of Vittorio Valori Perduti, we look for the authenticity of places where the railway stopped and which today are still there in the form of a ruin, from which it is possible to trace a metonymic profile through the microstorie of these microgeografie that the great Italian geographer Eugenio Turri reads approaching the Mincio Valley (cf. De Marinis/ Franchini/Jacometti 1993).

This is a personal story made by visions and images, descriptions that contain the references and the spirit of their authors. The architectural project becomes the outcome of a subjective culture that relates project and landscape through their representation and interpretation. 
References

Belpoliti, Marco (2021): Pianura (Plain-The Po Valley), Torino: Einaudi.

Calvino, Italo (1980): Una pietra sopra: discorsi di letteratura e società (A Stone Above: Discourses of Literature and Society), Torino: Einaudi.

Camerlenghi, Eugenio (2003): Lineamenti digeografia e storia del paesaggio agrario mantovano (Outlines of Geography and History of the Mantuan Agricultural Landscape), Mantua: Tre Lune Edizioni.

Dal Lago, Alessandro (1987), »La città immaginate: Viaggio in Italia a tappe. Parte I (Imagined Cities. A NineStage Journey around Italy. Part I), in: Architettura Cronache e Storia 377, 225-240.

De Marinis, Rafaele C./Franchini, Dario A./ Jacometti, G./ Lanza, C./ Laureti, L./ Lonardi, G./Marinelli, S./Monicelli, F./ Palvarini Cobio Casali, M.R./ Perbellini, G./ Turri, E. (1993): Il Mincio e il suo Territorio (The Mincio and its Territory), Verona: Cierre Edizioni.

De Seta, Cesare (2014): L'Italia nello specchio del Grand Tour (Italy in the Reflection of the Grand Tour), Milan: Rizzoli.

Chirri, Luigi/Leone, Gianni/Velati, Enzo (1984): Viaggio in Italia (An Italian Journey), Alessandria: II Quadrante.

Gregotti, Vittorio (1988), »lo scrivo che Omero racconta (I write about Homer telling), in: Casabella 546, 2-3.

Gregotti, Vittorio (2014): 96 ragioni critiche del progetto (96 Critical Reasons for the Project), Milan: BUR Saggi.

Lampugnani Magnago, Vittorio/Savi, Vittorio (1987): „Cronache di un Viaggio in Italia, del catalogo e della mostra « (Chronicles of a Journey in Italy, the Exhibition Catalog), in: XVII Triennale di Milano (eds.), Le città immaginate, un viaggio in Italia, nove progetti per nove città, Milan: Electa, 13-17.
Melville, Herman (1892): Moby Dick Or, the White Whale, Boston: L.C.Page \& Company Publishers.

Nicolin, Pierluigi (1987): »Introduzione« (Introduction), in: XVII Triennale di Milano (eds.), Le città immaginate, un viaggio in Italia, nove progetti per nove città, Milan: Electa, 11-12.

Pessoa, Fernando (2020): Teoria dell'eteronimia (Theory of Heteronymy), Macerata: Quodlibet.

Pine, Red (2009): Lao-tzu's Taoteching With Selected Commentaries from the Past 2,000 Years, Port Townsend, WA: Copper Canyon Press.

Pontiggia, Elena (1987), »Le Città Immaginate, un viaggio in Italia« (Imagined Cities, A Journey in Italy), in: Domus 683, 78-84.

Savi, Vittorio (1981): »ll paesaggio della pianura Padana (The Landscape of the Po Valley), in: paesaggio immagine e realtà, Milan: Electa, 275-282.

Spinelli, Luigi (2019): La visione soggettiva: progetti e paesaggi (The Subjective Vision: Projects and Landscapes), Milan: Franco Angeli.

Triennale di Milano (1987): Le città Immaginate. Un viaggio in Italia, Nove progetti per nove città (Imagined Cities. A Journey through Italy, Nine Projects for Nine Cities), Milan: Electa. 
